\title{
Research on the Incentive policy of Shale Gas in China and America
}

\author{
Liaoyi Ning ${ }^{1, a}$, Jinyuan Liu ${ }^{1, b}$ and Xuefeng $\mathrm{Wu}^{1, \mathrm{c}}$ \\ ${ }^{1}$ State Grid Liaoning electric power co., LTD., technical and economic research institute, Shenyang, \\ 110015, China. \\ aningliaoyi @163.com, b54624579@qq.com, ${ }^{\mathrm{c}} 13700007415 @ 126 . c o m$
}

Keywords: shale gas, fiscal policy, R\&D policy, market policy.

\begin{abstract}
The shale gas is the important supplement for the conventional energy, and increases the supply of clean energy. Therefore, a lot of countries have begun to pay attention to the development and utilization of shale gas in recent years, especially America and China. The policy plays an important role in the early stage of the shale gas development, especially the incentive policies. Based on this, the paper summarized and analyzed the shale gas incentive policies of China and American, and then provided some policy recommendation for the development of China's shale gas.
\end{abstract}

\section{Introduction}

The success of shale gas revolution in America attracted the attention of many countries, especially China. The exploitation of shale gas is a strategic option for China to achieve the security and diversify of energy supply, and it is necessary to exploit shale gas in the "12th Five-Year" energy Planning. In order to realize the industrial development of shale gas, Chinese government promulgated a series of policies.

The development of shale gas also attracted the scholars' attention. Mehmet Melikoglu analyzed the role of shale gas in the global energy market, and held that shale gas development was a must for global energy market [1]. Hongcai Fei et al. pointed out that China's shale gas development should be in light of the development experience of America's shale gas [2]. Based on the situation of shale gas exploration, Shizhen Li and Qun Zhao provided correlative suggestions for the future development of shale gas $[3,4]$. Shangbin Chen and Yunpeng Dong explored the trend and demands of China's shale gas development $[5,6]$. About the policies, Nan Wang et al. analyzed the shale gas development in America and Canada, and suggested that China draw experience from them [7]. Jing Ma et al. researched the technology and relevant policies of shale gas on America etc. to provide reference for China's shale gas development [8]. Based on the development experience of America's shale gas and China's coalbed methane, Yongyuan Liao provided some policy suggestion for China's shale gas development [9]. Desheng Hu discussed the opportunity, challenges and policy choices of China on developing shale gas [10]. Based on the existing research, the paper mainly analyzed incentive policies of shale gas in China and America, and provided some recommendation.

\section{Incentive policy}

Fiscal policy. America began to encourage the unconventional resources development in1970s, and issued a series of the policies for shale gas development (See Table 1). By now, the fiscal policy in America has been detailed, and the tax incentives of conventional gas have been applied to unconventional gas fields. Besides, America has also issued some corresponding tax breaks. In China, the subsidies framework of shale gas has been confirmed (See Table 2). China issued "The Notice about Introducing the Shale Gas Development and Utilization Subsidies” in 2012, increasing the financial supports for shale gas exploration and development and giving direct subsidies to the enterprises. On Oct. 2013, National Energy Administration issued “The Shale Gas Industrial Policy” and reiterated the terms of "the Subsidy Policy to Develop Shale Gas".

The fiscal policies in China and America are similar, especially the framework, but there are some difference. In America, the government is more inclined to give fiscal subsidies to shale gas 
enterprises. Besides, the subsidies take the local characteristics into account to make up for the deficiency of the central government's subsidies. While in China, the government tends to give tax breaks to shale gas enterprises, and the scope of tax breaks is more widely. Because the fiscal policies are made only for shale gas, the policies are more targeted and well combined with the characteristics of shale gas. In addition to the subsidies from central government, local governments can also give subsidies, but the local subsidy standards are not introduced.

Table 1 The major fiscal policies of America

\begin{tabular}{|c|c|c|}
\hline Year & Policies or measures & Contents \\
\hline 1978 & Natural Gas Policy Act of 1978 & $\begin{array}{l}\text { Ensure the unconventional gas subsidies by } \\
\text { Legislating. }\end{array}$ \\
\hline 1980 & $\begin{array}{l}\text { Windfall Profits Tax Act, Section } 29 \text { tax } \\
\text { credit for production of Non-conventional } \\
\text { fuels }\end{array}$ & $\begin{array}{l}\text { The unconventional gas drilled during } 1980 \text { and } \\
1992 \text { can enjoy a subsidy of \$ 3/barrel. }\end{array}$ \\
\hline 1992 & $\begin{array}{l}\text { Amendment of unconventional energy } \\
\text { production tax cuts and subsidies policies, } \\
\text { NO. } 29\end{array}$ & $\begin{array}{l}\text { Set up energy production tax allowance. Featuring } \\
\text { tax breaks for the shale gas drilled between } 1979 \text { and } \\
1999 \text { and produced before } 2003 \text {. }\end{array}$ \\
\hline 1992 & Energy Policy Act of 1992 & Extending the scope of subsidies. \\
\hline 1997 & Taxpayer Relief Act of 1997 & The tax subsidies are remained. \\
\hline 2005 & Energy Policy Act of 2005,section 1345 & $\begin{array}{l}\text { Unconventional reservoir wells that put into } \\
\text { operation in } 2006 \text { can obtain \$3/barrel of oil until } \\
2010 \text {. }\end{array}$ \\
\hline
\end{tabular}

Table 2 The major fiscal policies of China

Acts and Policies Contents

The Subsidy Policy to Subsidy standard of central government is $0.4 \mathrm{Yuan} / \mathrm{m}^{3}$ in 2012-2015 and it is Develop Shale Gas adjustable. Subsidies of local government are favoured.

The Shale Gas Industrial Shale gas development is put into national strategic emerging industries. Increase Policy, Chapter 7.NO.30 financial support.

The Shale Gas Industrial Direct subsidies are measured by the production. Enterprises should be audited. Policy, Chapter 7.NO.31 Government would withdraw the subsidies if there is any fraudulent behavior.

The Shale Gas Industrial Encourage local government to give subsidies to shale gas production enterprises Policy, Chapter 7.NO.32 according to the situation.

The Shale Gas Industrial Cut mineral resources compensation fees and mineral right fees. Plan to Policy, Chapter 7.NO.33 introduce tax incentives.

The Shale Gas Industrial Imported equipment or technologies of shale gas exploration and development Policy, Chapter 7.NO.34 are exempted from customs duties.

R\&D policy. Since 1980s, America formulated many policies to promote shale gas R\&D, and invested more than 60 billion dollars to explore unconventional gas. Lots of advanced technologies were applied in practice, increasing the production and lessening the mining cost. The R\&D policies in America have been successful, and it is continued to increase the support of R\&D. In 2004, America issued "Energy Act 2004" deciding to invest \$45 million/year for unconventional gas next 10 years. The experience of America's shale gas development provides reference for China. China should intensify policy support for the shale gas R\&D. As shown in Table 4, many R\&D policies have been issued in recent years.

Table 4 Main R\&D policies of China

Policies Contents

\begin{tabular}{|c|c|}
\hline \multirow[b]{2}{*}{ “China’s Energy } & \\
\hline & then basic and cutting-edge research and enhance the ability of technology \\
\hline Policy (2012)” & nd bulled the talent team. \\
\hline hale Gas & R\&D of shale gas key technology was listed as a key project in the large oil and gas \\
\hline Development & chnology jointly with \\
\hline Plan (2011-2015) & foreign research ins \\
\hline The Shale Gas & ate the self-independence of shale gas key technology and equipment. Intensify \\
\hline $\begin{array}{l}\text { Industrial Policy, } \\
\text { Chapter } 4 .\end{array}$ & $\begin{array}{l}\text { the construction of "National energy-shale gas research (experiment) centre" and other } \\
\text { R\&D platforms. }\end{array}$ \\
\hline
\end{tabular}


Both America and China made a series of policies to support the R\&D of shale gas, but invested capital in R\&D policies are different. China's policies tend to attract foreign advanced technology, and realize the nationalization and self-reliance of technology combined. America's policies are focused on independent R\&D. In China, the funding profile of shale gas is not clear and specific, and the incentive effect is not obvious, but it is failed to attract various talents into the field. The planning of China's R\&D policies may be reasonable, but the executive strength and implementation effect remains to be improved.

Market Policy. In America, the government has been trying to establish a free market for shale gas development. In addition to tax subsidies and technology research funds, the government enacted many legislations and policies to create a favorable competitive environment since 1978. Besides, the government also attached great importance to international cooperation in order to establish long-term energy and technology partnership (See Table 5). The market policies have good effects on the forming of the shale gas market, and many small and medium businesses have entered the field and played important roles.

Table 5 Major market policies of America

\begin{tabular}{|c|c|c|}
\hline Year & Policies or measures & Contents \\
\hline 1978 & Natural Gas Policy Act & $\begin{array}{l}\text { Wellhead price deregulation of shale gas. Attract some small } \\
\text { and medium-sized oil firms to join in the market }\end{array}$ \\
\hline 1985 & Order No. 436 (by FERC) & $\begin{array}{l}\text { Terminate bundled pricing and encourage gas transmission } \\
\text { without discrimination, end pipeline companies’ monopoly }\end{array}$ \\
\hline 1989 & $\begin{array}{l}\text { Natural Gas Wellhead Price } \\
\text { Lifting Scheme }\end{array}$ & $\begin{array}{l}\text { Thoroughly deregulation. Wellhead price of shale gas is } \\
\text { determined by market }\end{array}$ \\
\hline 1992 & Order I & $\begin{array}{l}\text { Pipeline companies are required to provide services based on } \\
\text { the separation of transportation and sales }\end{array}$ \\
\hline 2000 & Ord & $\begin{array}{l}\text { the efficiency of oil and gas transportation market to } \\
\text { he interests of markets players }\end{array}$ \\
\hline 2007 & $\begin{array}{l}\text { Energy Indepe } \\
\text { Act }\end{array}$ & $\begin{array}{l}\text { Establish international energy projects item to promote the } \\
\text { cooperation with other countries }\end{array}$ \\
\hline 2009 & $\begin{array}{l}\text { Promoting international } \\
\text { cooperation in clean energy }\end{array}$ & $\begin{array}{l}\text { Establish long-term cooperation relations to help other } \\
\text { countries develop shale gas. }\end{array}$ \\
\hline 2011 & "Bureau of Energy Resources" & Strengthen international cooperation in the energy field. \\
\hline
\end{tabular}

The shale gas development needs huge initial investment, and China should increase financing channels to make the market more competitive. Meantime, the government should strengthen international exchanges and cooperation to quicken the forming of effective system for investment financing. As shown in Table 6, China has listed shale gas as independent mineral to let shale gas free from the oil and gas franchise, and adopted the shale gas exploration tender system to open the market. The market policies place more emphasis on attracting international businessmen and capitals into the development of shale gas.

Table 6 Major market policies of China

\begin{tabular}{|c|c|c|}
\hline Year & Policies or measures & Contents \\
\hline 2012 & $\begin{array}{l}\text { Intention Survey for } \\
\text { Shale Gas } \\
\text { Exploration Right } \\
\text { Bidding }\end{array}$ & $\begin{array}{l}\text { Publish Bidding Qualifications. There are no other requirements except } \\
\text { that the registered capital should be more than } 300 \text { million Yuan. } \\
\text { Encourage other investors to enter the field. }\end{array}$ \\
\hline 2012 & $\begin{array}{l}\text { China's Energy } \\
\text { Policy (2012) }\end{array}$ & $\begin{array}{l}\text { Encourage private investment and cooperation with foreign firms. } \\
\text { Establish joint research collaboration intentions with Chevron, BP etc. } \\
\text { Companies can cooperate with foreign firms and introduce technology } \\
\text { after getting the pre-review and approval of government. }\end{array}$ \\
\hline 2013 & $\begin{array}{l}\text { The Shale Gas } \\
\text { Industrial Policy }\end{array}$ & $\begin{array}{l}\text { Introduce multiple investors. Standardize industry access and regulation. } \\
\text { Encourage local enterprises to join in shale gas market by joint ventures, } \\
\text { cooperation etc. Gradually form market structure in which shale gas } \\
\text { mining companies, sales companies and urban gas businesses coexist. } \\
\text { Ex-work price is determined by the market. Formulate fair trade rules, } \\
\text { encourage cooperation between the suppliers, transporters and demanders. }\end{array}$ \\
\hline
\end{tabular}


Both the market policies of China and America are inclined to deregulation and international cooperation, and break the monopoly and introduce competition. In order to break the monopoly of the mining license, Chinaese government encourages various investors to bid for the right of exploration. However, China's shale gas market is dominated by just a few state-owned enterprises at present. Thus, there requires further implementation of the market policies in China.

\section{Conclusions}

American issued a series of incentive policies, including giving tax breaks and subsidies, setting up special funds, creating diversified investment environment and sound market, and strengthening international communication. The policies greatly reduced the cost, and promote the development of shale gas industry in America. As for China, the government has also issued many policies to accelerate the development of shale gas industry. The relevant policies have begun to take shape in China, mainly including tax breaks and direct financial subsidies, increasing research funding, opening the market and strengthening international exchanges and cooperation. However, the local subsidy standards in China have not been introduced, the executive strength and implementation effect of incentive policies remains to be improved. China needs to make more efforts on policy supports. Firstly, China should be adjusted to local conditions and cannot blindly copy America's policy experience. Secondly, the local subsidies standards should be introduced soon. Thirdly, the cooperation and communication among government, enterprises and institutes should be strengthened.

\section{Acknowledgements}

The research work was supported by "Science and technology project funding by State Grid Liaoning electric power co., LTD” (Grant No.5222JJ14001F).

\section{References}

[1] Mehmet Melikoglu, Shale gas: Analysis of its role in the global energy market, J. Renewable and Sustainable Energy Reviews. 37(2014)460-468.

[2] Hongcai Fei, Yuhua Zhang, The Trend of US Future Energy Pattern and the Present Situation of China’s Shale Gas Exploration, J. Acta Geoscientia Sinica. 34(2013) 375-380.

[3] Shizhen Li, Dewu Qiao et al. The status of worldwide shale gas exploration and its suggestion for China, J. Geological Bulletin of China. 29(2010) 918-924.

[4] Qun Zhao, Dong Du et al. The Characteristic Analysis of the Different Types of Shale Gas Reservoir, J. SINO-GLOBAL ENERGY. 17(2012) 43-47.

[5] Shangbin Chen, Yanming Zhu et al. Research status and trends of shale gas in China, J. Acta Petrolei Sinica. 1(2013) 689-694.

[6] Yunpeng Dong, Xiaonan Ma, Shale gas and its development trend in China, J. Shandong Chemical Industry. 42 (2013) 50-53.

[7] Nan Wang, Danfeng Lei, Shale Gas Policy Implications of USA and Canada, J. International Petroleum Economics. 20(2012) 69-73.

[8] Jing Ma, Xiaomei Li et al. Development and policy analysis of shale gas resources abroad, J. Modern Mining. 8 (2012) 144-157.

[9] Yongyuan Liao, Dongkun Luo et al. Discussions of policy to promote China's shale gas development, J. Natural Gas Industry. 32(2012)1-5. 
[10]Desheng $\mathrm{Hu}$, Shengqing $\mathrm{Xu}$, Opportunity, challenges and policy choices for China on the development of shale gas, J. Energy Policy. 60(2013) 21-26. 